\title{
ギ酸を還元風とする無電解パラジウムめっきの析出機構
}

内田 衛*, 岡田 隆*, 縄舟秀美**, 中尾誠一郎**, 水本省三**

\section{Deposition Mechanism of Electroless Pd Plating \\ Using Formic Acid as a Reducing Agent}

\author{
Ei UCHIDA*, Takashi OKADA*, Hidemi NAWAFUNE**, Seiichiro NAKAO** \\ and Shozo MIZUMOTO**
}

Key Words : Electroless Pd Plating, Formic Acid, Mass Balance, Deposition Mechanism

\section{1. 緒言}

電子部品の接触部および接合部の表面処理では, 耐食 性, 接触抵抗およびはんだ付け性などの特性の優れた金 めっきが使用されてきた。しかし，金と下地金属材料と の相互拡散（ピットなどを通しての下地金属の表面拡散 速度は極めて大きい)，および金ースズ金属間化合物の 脆さに起因する接合強度の劣化などが問題視されるよう になり，金めっきの代替として無電解パラジウムめっき の使用が検討されるようになってきた。

無電解パラジウム合金めっきの還元剤として，次覀リ

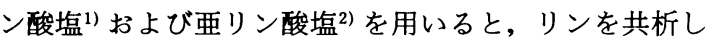
た皮膜が析出し，リンの共析量の増大に伴い皮膜硬さお よび電気抵抗の増大，およびはんだ付け性の劣化が生じ るため, 純パラジウム皮膜の得られる無電解めっき浴の 開発が要望されるようになってきた。既に報告したよう に，ギ酸を還元風とするエチレンジアミン (en) 錯体浴 からの無電解パラジウムめっきは可能であり, 平滑で緻 密なパラジウム皮膜が自己触媒的に析出する3)。

本研究では, ギ酸を還元剤とするエチレンジアミン錯 体浴からの無電解パラジウムめっきにおける，パラジウ ムの析出量およびギ酸の消費量を測定することにより, 析出機構を検討した。

\section{2. 実験方法}

基本めっき浴組成は, $0.01 \mathrm{~mol} / \mathrm{L} \mathrm{PdCl}_{2}, 0.08 \mathrm{~mol} /$ $\mathrm{L} \mathrm{en,} 0.2 \mathrm{~mol} / \mathrm{L} \mathrm{HCOOH}$ であり, $\mathrm{pH} 6$, 浴温 $60^{\circ} \mathrm{C}$

*石原薬品 ( 26)

ISHIHARA Chemical Co., Ltd. (5-26, Nishiyanagiharacho, Hyogo-ku, Kobe-shi, Hyogo 652-0806)

** 甲南大学 理学部（T658-8501 兵庫県神戸市東灘区岡本 89-1)

Fac.of Sci., Konan Univ. (8-9-1, Okamoto, Higasinadaku, Kobe-shi, Hyogo 658-8501)
基本めっき条件とした。析出速度は，ニッケルめっきを 施した銅板を素地として，めつき前後の重量変化から算 出した。ギ酸の消費量は, 表面積 $250 \mathrm{~cm}^{2}$ の電気ニッケ ルめっきを施した銅板を素地とし，ギ酸の消費量を大き くするため, 3 時間ごとにパラジウム塩を $0.1 \mathrm{~mol} / \mathrm{L}$ $\mathrm{PdCl}_{2}, 0.3 \mathrm{~mol} / \mathrm{L}$ en の溶液を補給しながらめっきを行 い, めっき後の溶液を超純水で 50 倍に希釈し，イオン クロマトグラフ法によりギ酸を定量した。溶離液には, $1.8 \mathrm{mmol} / \mathrm{L} \mathrm{Na}_{2} \mathrm{CO}_{3}, 1.7 \mathrm{mmol} / \mathrm{L} \mathrm{NaHCO}$ を用いた。 このように求めたギ酸の消費量と，パラジウムの析出量 とから還元剤の利用効率を求め, 析出機構を検討した。

\section{3. 実験結果および考察}

基本めっき浴組成およびめっき条件下において，各種 因子を個々に変化させた場合の析出速度を図 1 に示す。 析出速度に大きく影響する因子は, 塩化パラジウム濃度 と浴温であり, 析出速度は塩化パラジウム濃度の増大に 伴い増大し, 浴温の上昇に伴い直線的に増大した。エチ レンジアミン濃度およびギ酸濃度の析出速度に及ほす影 響は小さく，広い $\mathrm{pH}$ 領域において析出速度は約 1.5 $\mathrm{mg} / \mathrm{cm}^{2} \cdot \mathrm{h}$ の值を示した。また，この浴ではめっき反応 の進行に伴い炭酸塩が副成するが，炭酸水素イオンが蓄 積した場合においても，析出速度に及浔す影響は小さい。 $\mathrm{Pd}-\mathrm{P}^{1,2)}, \mathrm{Pd}-\mathrm{B}^{4)}$ 合金めっきでは安定剤としてチオジ グリコール酸を添加することにより平滑で緻密な皮膜が 得られ, 浴の安定性も改善されているが, 本浴ではチオ ジグリコール酸無添加において，平滑で緻密な皮膜が得 られ，浴の安定性も優れていた。

図 2 にめっき浴のイオンクロマトグラムを示す。保持 時間 $1.06 \mathrm{~min}$ にギ酸のピーク，1.76 min に塩化物イオ ンのピークが認められた。このことからめつき後の溶液 をイオンクロマトグラフ法により測定することで，ギ酸 の消費量を定量できるものと考えられる。ギ酸濃度を変 化させた基本めっき浴のクロマトグラムの，ギ酸のピー 


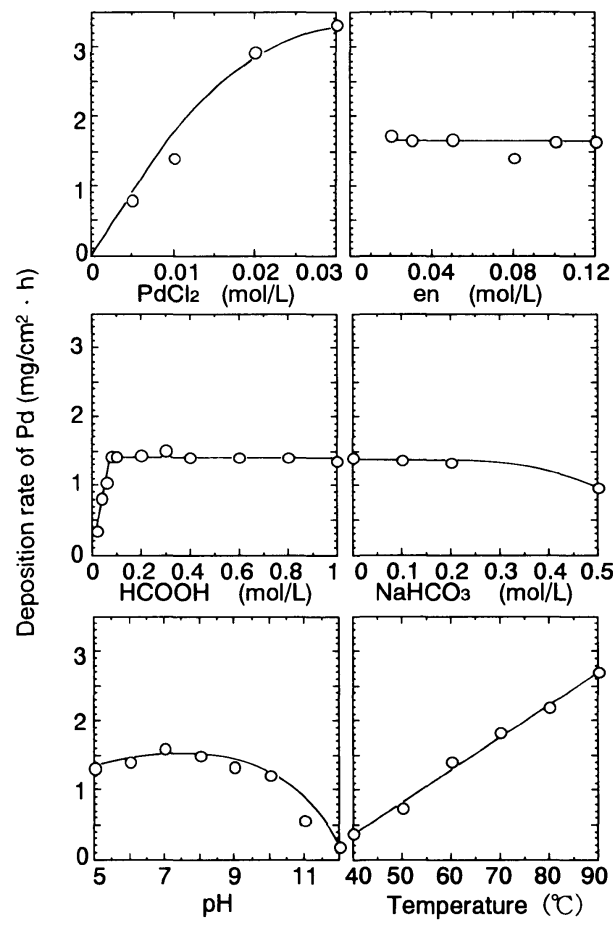

Fig. 1 Effects of bath components and plating conditions on deposition rate.

ク面積とギ酸濃度との間には良好な直線関係が得られた ことからこれを検量線として用いた。

めっき後(めっき時間 12 時間, 21 時間, 27 時間)の溶 液のイオンクロマトグラムのピーク面積から求めたギ酸 濃度からギ酸の消費量を算出し, パラジウムの析出量と ギ酸の消費量および還元剤の利用効率の関係を求めた結 果を図 3 に示す。ここで還元剤の利用効率は，ギ酸の消 費量に対するパラジウムの析出量の比を百分率で表した ものである。パラジウムの析出量の増大に伴いギ酸の消 費量は直線的に增大し，パラジウム析出に対する還元剤 の利用効率はほほ $100 \%$ を示した。このことから，次带 リン酸塩や垔リン酸塩を還元剤とした場合に見られるよ うな局部アノード反応における水素発生はないものと考 えられ，めつき反応の進行に伴う，若干の気泡の発生は， ギ酸の酸化生成物である炭酸ガスであると考えられる。 以上の結果より，ギ酸を還元剤とするエチレンジアミン 錯体浴からの無電解パラジウムめっきの析出機構は, 局部アノード反応

$$
\mathrm{HCOO}^{-}+\mathrm{H}_{2} \mathrm{O} \rightarrow \mathrm{HCO}_{3}^{-}+2 \mathrm{H}^{+}+2 \mathrm{e}^{-}
$$

局部カソード反応

$$
\mathrm{Pd}^{2+}+2 \mathrm{e}^{-} \rightarrow \mathrm{Pd}
$$

であると考えられる。

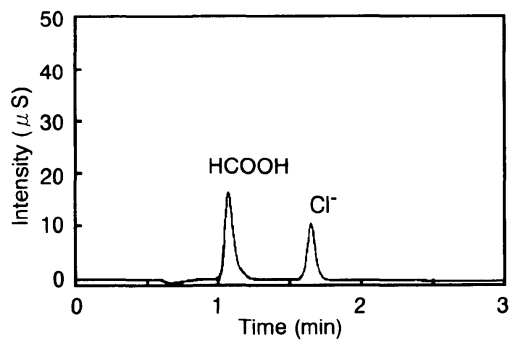

Fig. 2 Chromatogram of plating solution.

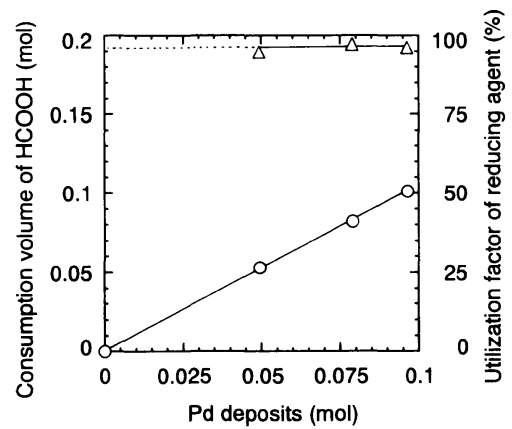

Fig. 3 Consumption of $\mathrm{HCOOH}$ with $\mathrm{Pd}$ deposition and utilization factor of reducing agent.

\section{4. 結言}

ギ酸を還元剤とするエチレンジアミン錯体浴からの無 電解パラジウムめつきは，中性および比較的低温度で めっきが可能であり, 浴の安定性にも優れ, 平滑でち密 なパラジウム皮膜が自己触媒的に析出した。

パラジウム析出に対する還元剤の利用効率はほほ 100\%であり，パラジウムの析出に，ほほ等 $\mathrm{mol}$ のギ酸 が消費されることが確認された。このことから，ギ酸を 還元剈とするエチレンジアミン錯体浴からの無電解パラ ジウムめっきでは，ギ酸の酸化反応により生じた電子の すべてがパラジウムイオンの還元に利用され，次亜リン

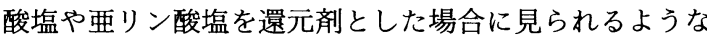
局部アノード反応における水素発生はないものと考えら れる。

(Received March 4, 1999 ; Accepted April 7, 1999)

\section{文献}

1）水本省三, 縄舟秀美, 内田 衛, 芳賀正記 ; 表面技術, 40, 477 (1989)

2 ) 芳賀正記, 内田 衛, 水本省三, 縄舟秀美 ; 表面技術, 42, 90 (1991)

3）縄舟秀美, 中尾誠一郎, 水本省三, 内田 衛, 岡田 隆 ; 表面 技術, 48, 474 (1997)

4）縄舟秀美, 上浦有紀, 水本省三, 芳賀正記, 内田 衛; 回路実 装学会誌, 11, 262 (1996) 